\section{PCR-based Method to Map the Bending Locus of DNA Molecules}

\section{Fernando Valle}

Instituto de Biotecnologia, Universidad Nacional Autónoma de México Chamilpa, Cuernavaca, Morelos 62210, Mexico
The existence of static curves in DNA is well documented. They have been found in several cellular and viral genomes, from Archeobacteria to human. Numerous proposals have been made that DNA curvature is of functional importance in a wide variety of biological processes, including replication, transcription, recombination, and chromatin organization. ${ }^{(1)}$ One characteristic of a curved DNA fragment is its anomalous slow electrophoretic mobility, which is more pronounced when the curvature is near the middle of the fragment.

The most common method of mapping the element responsible for the curvature in DNA molecules is the permutation assay. (2) For this assay, tandem repeats of the DNA region under study need to be constructed. Digestion of these repeats with restriction enzymes that cut only once produces a set of circularly permuted fragments, where the element(s) responsible for the curvature is (are) positioned at different distances from one end of the DNA fragment. Two limitations of this procedure are (1) the need to construct and clone tandem repeats; and (2) for a proper mapping, the presence of several unique restriction sites in the DNA fragment is required.

In this paper a simple procedure for the mapping of the region(s) responsible for the curvature is described. It uses PCR to generate the circularly permuted fragments. To test this procedure, the DNA region of the bacteriophage $\lambda$ origin of replication, which contains a sequenceinduced bent region, ${ }^{(3)}$ was analyzed.

\section{MATERIALS AND METHODS}

Five pairs of oligonucleotide primers, complementary to specific DNA regions of bacteriophage $\lambda$ were synthesized on a DNA Synthesizer model 381A (Applied Biosystems, Foster City, CA).

They were used to generate, by PCR, five 194-bp DNA fragments, where a specific DNA region was circularly permuted. The sequences of the primers, as well as their positions on the bacteriophage $\lambda$ sequence, ${ }^{(4)}$ are presented in Table 1. For PCR amplifications, 40 pmoles of each primer and $0.25 \mu \mathrm{g}$ of bacteriophage $\lambda$ DNA (Sigma, St. Louis, MO) were used in each reaction. They were carried out in 100- $\mu$ l reactions, using the GeneAmp PCR kit (Perkin-Elmer Cetus, Emeryville, CA). The amplification took place in an ISS Programmable Oven I (Integrated Separation Systems, Natick, MA) with the following procedure: After denaturating the DNA by heating the reaction mixture at $93^{\circ} \mathrm{C}$ for $10 \mathrm{~min}, 25$ cycles of PCR were performed with denaturation at $93^{\circ} \mathrm{C}$ for $1 \mathrm{~min}$, annealing at $60^{\circ} \mathrm{C}$ for $45 \mathrm{sec}$, and extensions at $65^{\circ} \mathrm{C}$ for $30 \mathrm{sec}$.

To analyze the PCR products, $3 \mu$ of each PCR reaction was loaded onto an $8 \%$ polyacrylamide gel with $1 \times$ TBE and separated at $120 \mathrm{~V}$ in the cold room. After staining with ethidium bromide and destaining in water, a picture of the gel was taken with an Eagle Eye video system (Stratagene, San Diego, CA).

\section{RESULTS AND DISCUSSION}

The general strategy for mapping the position of the bent DNA region of the bacteriophage $\lambda$ origin of replication consisted of generating (by PCR) five DNA fragments of 194 bases. The beginning

TABLE 1 Primer Sequences and Their Positions on the Bacteriophage $\lambda$ Nucleotide Sequence

\begin{tabular}{lll}
\hline Name & Sequence 5' $\rightarrow 3^{\prime}$ & Position \\
\hline A & CAGCAAGGCGGCATGTTTGG & 38986 to 39005 \\
B & TTCGCCAGAAT TCTCTGACG & 39161 to $39180^{\mathrm{a}}$ \\
C & GTGCATCCCTCAAAACGAGG & 39030 to 39049 \\
D & TCCGGTTTCACCACAGAAAG & 39205 to $39224^{\mathrm{a}}$ \\
E & ACGGTGCAATGAAGCCAAGT & 38937 to 38956 \\
F & GTGTCTTTTGTGTCCCCCTG & 39112 to $39131^{\mathrm{a}}$ \\
G & CCCTCAAATTGGGGGATTGC & 39080 to 39099 \\
H & CGGTCAGGTCTTCTGCTGTC & 39255 to $39274^{\mathrm{a}}$ \\
I & CCGATTCTCAACT TAGCGAG & 38887 to 38906 \\
J & GGATGTTTTATCCCTCGTTT & 39062 to $39081^{\mathrm{a}}$ \\
\hline
\end{tabular}

See Ref. 4.

aThe position of the complementary strand is indicated. 
A

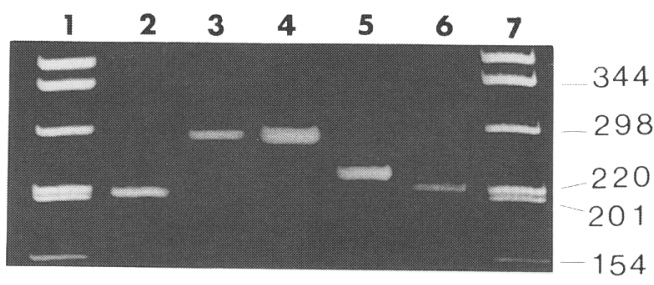

B

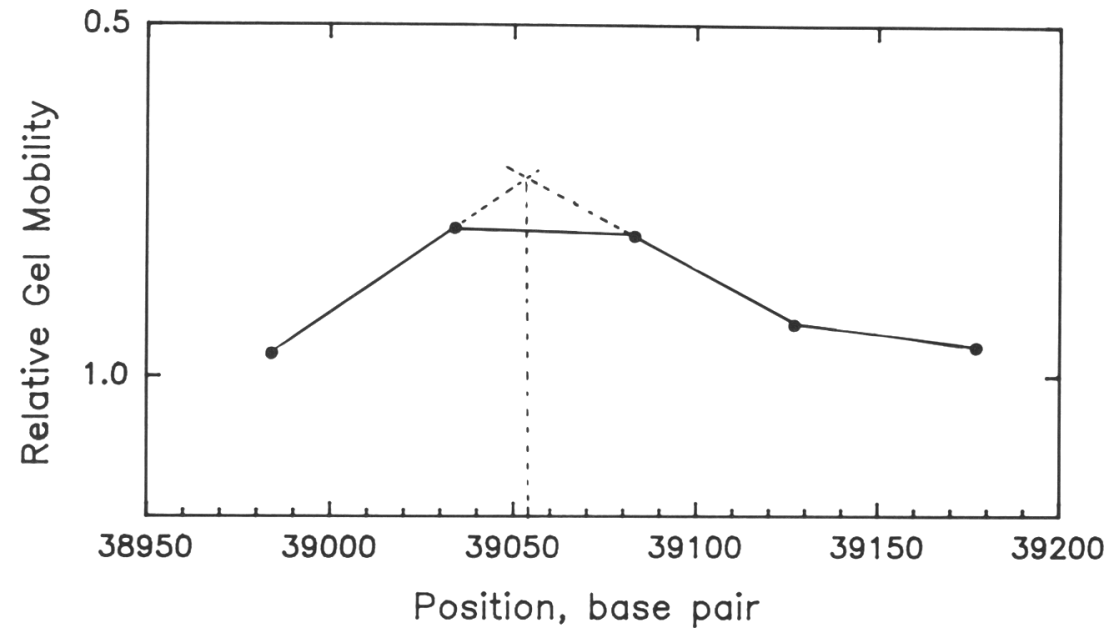

FIGURE $1(A)$ Electrophoretic separataion (8\% polyacrylamide gel) of PCR products generated using the following primer combinations: (Lane 2) $\mathrm{I}+\mathrm{J}$; (lane 3) $\mathrm{E}+\mathrm{F}$; (lane 4) A+B; (lane 5) $\mathrm{C}+\mathrm{D}$; (lane 6) $\mathrm{G}+\mathrm{H}$. (Lanes 1,7 ) Plasmid pBR322 digested with Hinfl used as size marker. $(B)$ Mapping of sequence-induced DNA curvature. The relative gel mobilities of the DNA fragments, separated on an $8 \%$ polyacrylamide gel $(A)$, were plotted against the position of the center of each DNA fragment. The position at which maximal gel retardation should have occurred (nucleotide 30952 of the phage $\lambda$ DNA sequence) was extrapolated from the graph and is indicated by broken lines.

of each fragment (with respect to the bacteriophage $\lambda$ sequence) varied by $\sim 50 \mathrm{bp}$.

After performing the amplification reactions and separating the DNA fragments on a polyacrylamide gel (see Fig. $1 \mathrm{~A})$, their relative gel mobility was calculated as the observed distance migrated, divided by the expected distance. These data were plotted against the position of the center of each DNA fragment, as shown in Figure 1B. From this graphic it was possible to extrapolate the position at which maximal gel retardation should have occurred. This position was nucleotide 39052 of the phage $\lambda$ DNA sequence. Previously, Zahn and Blattner localized the same site on nucleotide 39040 . $^{(3)}$ However, in that report the precision of the mapping was limited because the region from nucleotides 30940 to 39069 lacks unique restriction sites. ${ }^{(3)}$

Compared with the common circular permutations procedure, ${ }^{(2)}$ the method described in this paper is faster, easier to perform, and is not limited by the presence of unique restriction sites on the DNA under analysis. Also, it offers an unlimited supply of DNA fragments to study DNA-protein interactions. In this sense, PCR has been used to prepare microgram quantitites of double-stranded DNA fragments for use in experiments such as gel shift assays, specific mutagenesis, ${ }^{(5)}$ DNase I footprinting, and in vitro transcription. ${ }^{(6)}$

\section{ACKNOWLEDGMENTS}

I thank Dr. Edmundo Calva for critical reading of the manuscript and Paul Gaytan and Eugenio Lopez, at the Oligonucleotide Synthesis Facility at this Institute, for synthesizing the oligonucleotides used in this work. This work was supported by grant 0250-N91107 from the Consejo Nacional de Ciencia y Tecnologia, Mexico.

\section{REFERENCES}

1. Hagerman, P.J. 1990. Sequence-directed curvature of DNA. Annu. Rev. Biochem. 59: 755-781.

2. Wu, H.M. and D.M. Crothers. 1984. The locus of sequence-directed and protein induced DNA bending. Nature 308: 509513.

3. Zahn, K. and F.R. Blattner. 1985. Sequenceinduced DNA curvature at the bacteriophage origin of replication. Nature 317:451453.

4. Daniels, D.L., J.L. Schroeder, W. Zybalski, F. Sanger, A.R. Coulson, G.F. Hong, D.F. Hill, G.B. Petersen, and F.R. Blattner. 1983. Complete annotated lambda sequence. In Lambda II (ed. R. Hendrix, J. Roberts, F. Stahl, adn R. Wiesberg), pp. 519-676. Cold Spring Harbor Laboratory, Cold Spring Harbor, New York.

5. Higuchi, R., B. Krumel, and R.K. Saiki. 1988. A general method of in vitro preparation and specific mutagenesis of DNA fragments: Study of protein and DNA interactions. Nucleic Acids Res. 16: 73517367.

6. Krummel, B. and R. Chamberlin. 1989. RNA chain initiation by Escherichia coli RNA polymerase. Structural transitions of the enzyme in early ternary complexes. Biochemistry 28: 7829-7842.

Received Febrary 8, 1994; accepted in revised form June 24, 1994. 


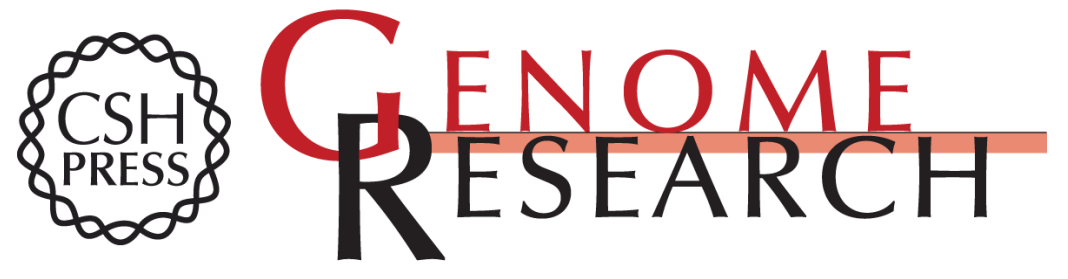

\section{PCR-based method to map the bending locus of DNA molecules.}

F Valle

Genome Res. 1994 4: 44-45

\section{License}

Email Alerting Receive free email alerts when new articles cite this article - sign up in the box at the Service top right corner of the article or click here.

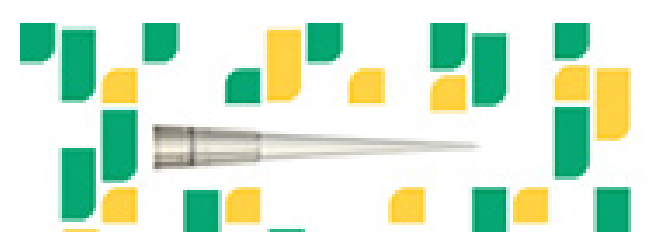

To subscribe to Genome Research go to: https://genome.cshlp.org/subscriptions 